\section{Watson's folly}

\section{Debate about sensitive scientific issues needs to be forthright but not crass.}

S: o 'Honest Jim' Watson has finally fallen victim to his notorious propensity for making outrageous statements - forced to cancel a UK lecture tour and suspended from his leadership role at Cold Spring Harbor Laboratory in New York after being quoted in a British newspaper as claiming that black people are less intelligent and employable than whites (see page 960).

Watson certainly has a track record in making distasteful remarks. He has on many previous occasions voiced unpalatable views tinged with racism and sexism, ranging from a desire to see a world full of genetically engineered pretty girls to his belief that sex drive is related to skin colour. He has been largely indulged over the years, mostly in light of his towering achievement of 54 years ago in helping to deduce the structure of DNA, his ensuing Nobel prize, and his role in founding the Human Genome Project.

His latest outburst marks the point at which his views have finally been deemed beyond the pale. And rightly so - for one of the world's most high-profile scientists to state such views demonstrates a sheer unacceptable offensiveness. Watson has apologized and retracted the outburst, claiming to have been "mortified" at the outcome of the interview although he did not deny its contents. He acknowledged that there is no evidence for what he claimed about racial differences

in intelligence. But the damage has been done, lending succour and comfort to racists around the globe.

Given the media storm breaking as the week progressed, it would have required remarkable bravery on the part of those hosting Watson's speaking engagements - part of the launch of his new book - to persist with them. Several high-profile establishments cancelled. This is regrettable: science is about nothing if not openness and critical debate. Scientists with controversial arguments need to be able to withstand the heat, defending or retracting statements as

"The damage has been done, lending succour and comfort to racists around the globe."

the evidence indicates is required. Watson, however unpleasant his utterances, has always been willing to act in this spirit.

The cancellations run the risk of playing into the hands of those who wish to suppress scientific inquiry. Many human geneticists are engaged in the sensitive task of unravelling differences between the world's population groups, all the while acknowledging that 'race' is an emotive and unscientific word. Others are investigating the equally sensitive genetics of 'desirable' traits, such as cognitive ability.

Asking such questions has always been controversial, given the potential for abuse of the outcomes demonstrated by the history of eugenics. Scientists explore the world as it is, rather than as they would like it to be. There will be important debates in the future as we gain a fuller understanding of the influence of genetics on human attributes and behaviour. Crass comments by Nobel laureates undermine our very ability to debate such issues, and thus damage science itself.

\title{
Going it alone
}

\section{The likely derailment of a US-Indian nuclear deal highlights the limitations of bilateral arrangements.}

n March 2006, US President George Bush and Indian Prime Minister Manmohan Singh reached an unprecedented agreement for civilian nuclear cooperation between the two nations. In exchange for India opening up a portion of its reactors to inspection by the International Atomic Energy Agency (IAEA), the United States would agree to lift sanctions that prevent nuclear trade.

Non-proliferation advocates were critical of the move. A moratorium on nuclear cooperation with India has been in place for decades as a consequence of its failure to sign the nuclear nonproliferation treaty (NPT), which allows nations access to civilian nuclear technology as a quid pro quo for not developing nuclear weapons. India never signed the NPT and has developed nuclear weapons.

Critics argued that by arranging to sell India nuclear power technology, the United States was undermining the NPT's already shaky foundations. But the agreement was consistent with the Bush adminstration's penchant for pursuing bilateral, one-off deals, which its officials argue are easier to negotiate and more in line with US interests than multilateral treaties.

Supporters said that the IAEA inspections would bring India closer to the norms of the global non-proliferation regime, and that it was better for some of the country's facilities to be open to inspection than none at all.

But on 22 October, the Indian government announced that the treaty would not be approved by the end of this month, as had been hoped - raising fears that it will drift into abeyance. The Communist Party, the third largest party in the Indian parliament, has threatened to pull out of the fragile coalition government if the deal goes ahead. It opposes the deal because it would mean closer ties with the United States, possibly at the expense of relations with China. Meanwhile, the right-wing Bharatiya Janata Party has also voiced opposition, arguing that parts of the agreement would interfere with India's national defence interests.

As a result, this episode could be poised to undermine the international non-proliferation regime on two fronts. Its initiation showed that the world's largest nuclear power was ready, for the first time, to trade with nuclear states outside the NPT. But the current difficulties suggest that international inspections and other benefits to non-proliferation won't be realized from such agreements any time soon.

Bilateral arms-control deals are highly vulnerable to changes in the political climate inside either partner nation, and can undercut the legitimacy of truly international efforts. The latter have many weaknesses, but their basic permanence provides a firm foundation on which relations between nations can be built. It would be better for all involved if countries such as India and the United States eschewed bilateral fixes and got behind the further development of the existing international framework for non-proliferation. 